\title{
Monitoring and Prediction of Climate Change Impact on 24-h Probable Maximum Precipitation in the Southeast of Caspian Sea
}

\section{Zahra Afzali-Gorouh}

Ferdowsi University of Mashhad Faculty of Agriculture

Alireza Faridhosseini ( $\square$ farid-h@um.ac.ir)

Ferdowsi University of Mashhad Faculty of Agriculture

Bahram Bakhtiari

Shahid Bahonar University Faculty of Agriculture

Abolfazl Mosaedi

Ferdowsi University of Mashhad Faculty of Agriculture

Nasrin Salehnia

Seoul National University

\section{Research Article}

Keywords: Extreme events, Widespread storms, maximum 24-h precipitation, Climate scenarios, Flood.

Posted Date: November 2nd, 2021

DOI: https://doi.org/10.21203/rs.3.rs-1027760/v1

License: (9) This work is licensed under a Creative Commons Attribution 4.0 International License. Read Full License 


\title{
Monitoring and Prediction of Climate Change Impact on 24-h Probable Maximum Precipitation in the Southeast of Caspian Sea
}

\begin{abstract}
Due to the impacts of climate change on Probable Maximum Precipitation (PMP), and its importance in designing hydraulic structures, PMP estimation is crucial. In this study, the effect of climate change on 24-h probable maximum precipitation $\left(\mathrm{PMP}_{24}\right)$ was investigated in a part of the Qareh-Su basin located in the Southeast of Caspian Sea. So far, there are no studies emphasizing on climate change impact on hydrological (physical) PMP values have been
\end{abstract} conducted in the study area. For this purpose, the climatic data were applied during the years 19882017. To generate future data, the outputs of the CanESM2 (Second Generation Canadian Earth System Model) model as a general circulation model (GCM) under optimistic (RCP2.6), middle (RCP4.5), and pessimistic (RCP8.5) emission scenarios, and statistical downscaling model (SDSM) were used in the near (2019-2048) and the far (2049-2078) future periods. The $\mathrm{PMP}_{24}$ values were estimated using a physical method in the baseline and future periods under the three scenarios. The $\mathrm{PMP}_{24}$ value was estimated at $143 \mathrm{~mm}$ for the baseline-period, using a physical approach. These values were 98, 105, and 109 for the near-future and 129, 122, and 126mm for the far-future period. The results showed that the physical approach's $\mathrm{PMP}_{24}$ values tend to fall at 14-38\%. Overall, the $\mathrm{PMP}_{24}$ values decrease in the future, and the rate of decrease in the nearfuture was more than the rate of the far-future. The spatial distribution maps of $\mathrm{PMP}_{24}$ in the baseline and future-periods showed that the $\mathrm{PMP}_{24}$ values decreased from west to east.

Keywords: Extreme events, Widespread storms, maximum 24-h precipitation, Climate scenarios, Flood. 


\section{Introduction}

Intensive rainfall and heavy floods are the most catastrophic natural hazards that have enormous social consequences for communities worldwide. In Iran, flood is one of the most devastating natural hazards that occur frequently (Shaffie et al. 2019). The Caspian Sea region, particularly in Golestan Province, has experienced many heavy flood events. The worst and catastrophic flood occurred in August 2001, in which many people have died. Another massive flood occurred in March 2019, which resulted in an extensive inundation of lowlands. These events were the apparent evidence of climate change created due to human intervention in nature in the last decades (Sharifi et al. 2012; Gharibreza, 2019).

To reduce the destructive effects of these phenomena, flood risk management is essential. One of the crucial components in flood risk management is probable maximum flood (PMF) estimation. Hydrologists use PMF to design hydrologic infrastructure types in a given basin, such as significant spillways, dam storage capacity, and flood protection structures. To calculate PMF accurately, it is necessary to calculate the probable maximum precipitation (PMP) (Liu et al. 2018). PMP has been defined as "the greatest depth of precipitation for a certain duration meteorologically possible for a given size storm area at a specific time of year (WMO 1986, 2009)".

\section{The World Meteorological Organization has widely proposed statistical, and hydro-} meteorological (physics-based) approaches for estimating PMP (WMO, 2009). A statistical approach is a probabilistic procedure that requires a statistical analysis based on the extreme historical precipitation at the meteorological stations where at least 30 years of daily data are available. Several statistical approaches have been used to derive PMP, such as Hershfield method (Hershfield, 1961, 1965), Multifractal (Douglas and Barros, 2003), Traditional frequency analysis methods or different statistical distributions such as the generalized extreme value (GEV) 
(Vivekanandan, 2015; Deshpande et al. 2008) and Fisher-Tippett and beta distributions (Nobilis et al. 1991).

Hydro-meteorological estimation approaches can usually be divided into various methods, such as (a) the storm model approach, (b) the generalized method, (c) the moisture maximization method, and (d) the storm transportation method. More detail about these methods was mentioned in Rezacova et al. 2005; Rakhecha and Singh, 2009; WMO, 2009; Collier and Hardaker, 1996; Beauchamp et al. 2013; Rakhecha et al. 1995; Papalexiou and Koutsoyiannis, 2006; Casas et al. 2011; Micovic et al. 2015, Rouhani and Leconte, 2016. However, based on the comparison of studies, there are no generally recommended approaches for PMP estimation (WMO 2009).

There have been several studies about PMP estimation using the hydro-meteorological and statistical approaches in different parts of Iran (Ghahraman, 2008; Naseri Moghaddam et al. 2009; Fattahi et al. 2010, Shirdeli, 2012). Whereas, there have been few efforts to investigate climate change's impact on Iran's PMP values in recent years.

Naseri Moghadam et al. (2009) estimated a 1-day PMP for 23 meteorological stations in four central provinces of Iran using the Hershfield method. Their emphasis was to correct the frequency factor of this method for these stations. Their results indicated that the highest value of the frequency factors was 7.6. In another study, Soltani et al. (2014) estimated PMP using statistical and physical approaches for the central regions of Iran. They observed that PMP estimated using the statistical approach was more significant than estimated using the physical approach.

Despite several studies on PMP estimates in Iran, there are just two studies about the Investigation of climate change impacts on PMP values for different regions of Iran. Afrooz et al. (2015) investigated the effects of climate change on probable maximum precipitation in the southern part of Iran using the outputs of two Global Circulation Models (HadCM3 and CGCM3) under A2 emission scenario utilizing three statistical downscaling methods; namely Change Factor 
70 (CF), Statistical Downscaling Model (SDSM), and Long Ashton Research Station Weather

71 Generator (LARS-WG). This study used the statistical method to estimate the PMP in the baseline 72 (1971-2000) and the future (2011-2040) periods. Their results showed that PMP amounts increased up to $18.2 \%$ and $27.3 \%$, respectively, by different study areas. Ramak et al. (2017) investigated the climate change impacts on probable maximum precipitation under three scenarios $(\mathrm{A} 1 \mathrm{~B}, \mathrm{~A} 2$, and B1) in the Karun catchment (located in the southwest of Iran). It is established that the PMP values for 24, 48, and 72 hours are 127,170 , and $185 \mathrm{~mm}$, respectively. The results demonstrated that the PMP value would decrease by up to 5\% under the A1B scenario and increase by up to 5\% and $10 \%$ under A2 and B1 scenarios. Lee et al. (2017) suggested a method to calculate the extreme precipitation in Korea using the Weather Research and Forecasting (WRF) model as a regional climate model. They determined the extreme historical precipitation, reconstructed this event using the WRF model, and then calculated PMP (RCM-PMP). Finally, their results revealed that there is a good agreement between RCM-PMP and existing PMP. In the other research, Lee and Kim (2018) investigated the impact of climate change on future PMPs in Korea using the outputs of three regional climate models provided by CORDEX under RCP scenarios. Their results showed that future PMPs in Korea would have ascending trend, but future PMPs' spatial distribution will be similar to the present.

The Caspian Sea and the ranges of Alborz Mountain are geographical phenomena in the north of Iran that affect rainfall in the southern parts of the Caspian Sea, including the Qareh-Su basin. Furthermore, due to climate change's impacts on extreme precipitation and floods across the study area, hydraulic structures' safety and security would be affected. Therefore, the design rainfall must evaluate under various future climate conditions to design and assess large hydraulic structures. Although the values of $\mathrm{PMP}_{24}$ was estimated over the Qareh-Su basin using the statistical and physical method by Afzali-Gorouh et al. (2018), owing to the importance of the 
94 climate change impacts on PMP and our literature review, it was determined that so far, there are no studies with emphasis on climate change impact on hydrological (physical) PMP values have been conducted in the study area. Therefore, this study will analyze the effects of future climate change conditions on the PMP over the north of Iran. Thus, the present study was undertaken to achieve the following objectives:

1. to estimate the 24-h PMP $\left(\mathrm{PMP}_{24}\right)$, provide the $\mathrm{PMP}_{24}$ spatial distribution maps for the baseline and the future periods using the physical method,

2. to determine the regions that are more likely to experience intense storms for the baseline period,

3. to determine the regions that are more likely to experience intense storms under changing climate conditions for the future period,

4. to assess the behavior of the PMP in response to changing climate conditions.

\section{Materials and Methods}

\subsection{Study Area and Datasets}

Iran is located in the southwest of Asia. It is a mountainous country where two major mountain chains, the Alborz Range and the Zagros Range, dissect the country into climactic zones. The Caspian Sea is situated in the northern sector, providing maritime influences. Qareh-Su basin is located between longitudes $54^{\circ} 02^{\prime} 04^{\prime \prime}$ to $54^{\circ} 42^{\prime} 57^{\prime \prime}$ E and latitudes $36^{\circ} 59^{\prime} 29^{\prime \prime}$ to $36^{\circ} 36^{\prime} 54^{\prime \prime} \mathrm{N}$ in the southeastern parts of the Caspian Sea covering approximately $1760 \mathrm{~km}^{2}$, and has a topography range from -84 to $3221 \mathrm{~m}$. Based on De Martonne's classification; this area is contained sub-humid- warm, humid- moderate, and sub-humid- moderate climates based on Extended De Martonne classification (Rahimi et al. 2013). This area experiences heavy rainfalls and floods (Afzali-Gorouh et al. 2018). Fig. 1 shows the elevation variations, study area, and 

and their climates based on Extended De Martonne classification are shown in Table 1.

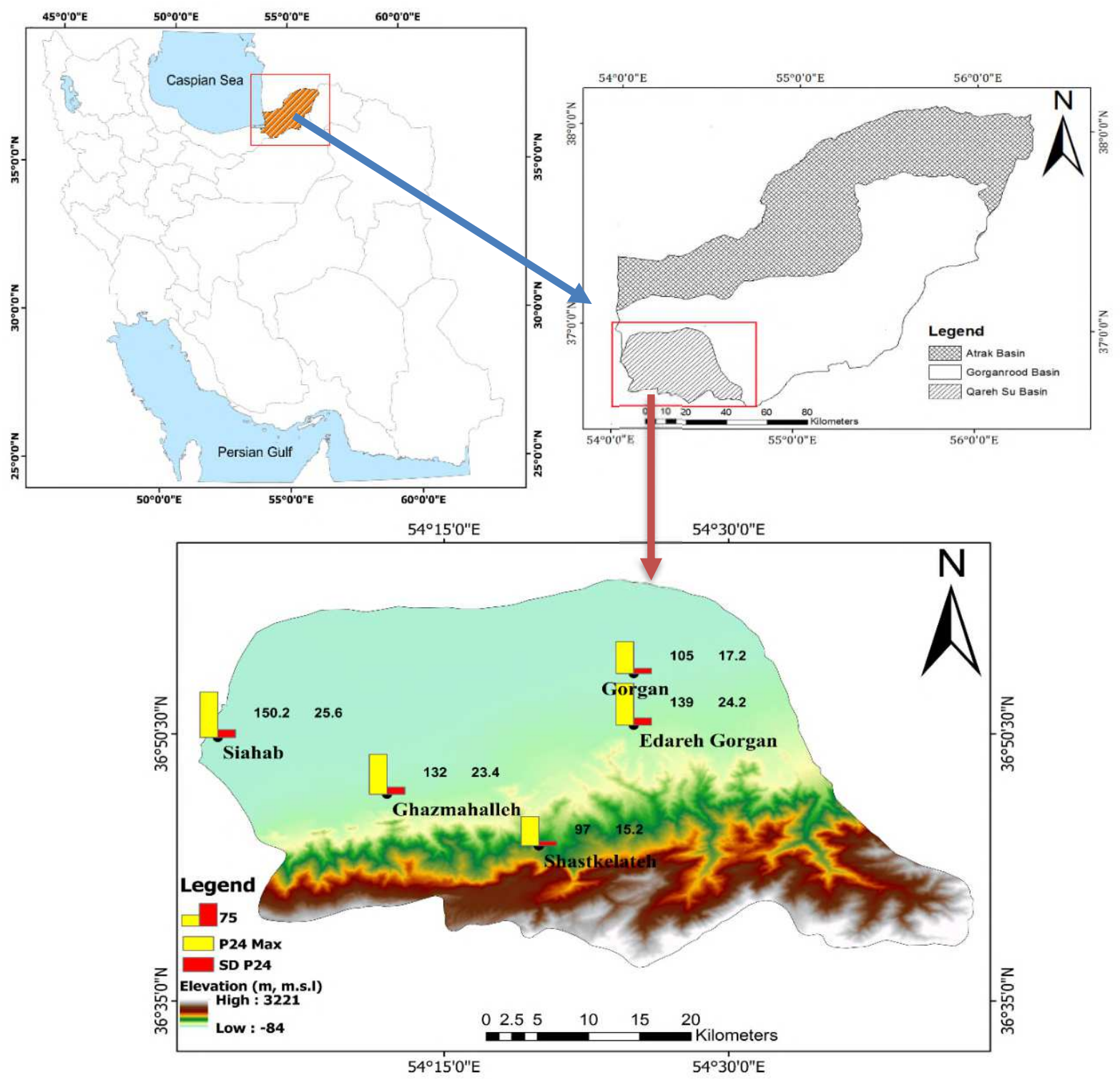

Fig. 1 The elevation variations, geographical location, and maximum and standard deviation of 24-hour precipitation of the study stations 
121 Table 1 Geographical and climatological characteristics of the study stations and their climates during the period of $122 \quad 1988-2017$

\begin{tabular}{|c|c|c|c|c|c|c|c|c|}
\hline \multirow{2}{*}{ Station } & \multirow{2}{*}{$\begin{array}{c}\text { Latitude } \\
\text { (N) }\end{array}$} & \multirow{2}{*}{$\begin{array}{c}\text { Longitude } \\
\text { (E) }\end{array}$} & \multirow{2}{*}{$\begin{array}{c}\text { Elevation } \\
\text { (m) }\end{array}$} & \multicolumn{4}{|c|}{ 24-h precipitation $(\mathrm{mm})$} & \multirow{2}{*}{$\begin{array}{l}\text { Climate classification } \\
\text { Based on Extended De } \\
\text { Martonne Classification }\end{array}$} \\
\hline & & & & Max. & Avg. & Min. & SD & \\
\hline Edareh Gorgan & $36^{\circ} 51^{\prime}$ & $54^{\circ} 25^{\prime}$ & 75 & 139 & 47.3 & 17 & 24.2 & Sub-humid- Warm \\
\hline Ghazmahalleh & $36^{\circ} 47^{\prime}$ & $54^{\circ} 12^{\prime}$ & 6 & 132 & 54.4 & 21 & 23.4 & Sub-humid- Warm \\
\hline Shastkelateh & $36^{\circ} 44^{\prime}$ & $54^{\circ} 20^{\prime}$ & 150 & 97 & 51.3 & 25 & 15.2 & Humid- Moderate \\
\hline Gorgan & $36^{\circ} 54^{\prime}$ & $54^{\circ} 25^{\prime}$ & 13.3 & 105 & 50.9 & 28.8 & 17.2 & Sub-humid- Warm \\
\hline Siahab & $36^{\circ} 50^{\prime}$ & $54^{\circ} 03^{\prime}$ & -26 & 150.2 & 53.6 & 20.4 & 25.6 & Sub-humid- Moderate \\
\hline
\end{tabular}

To estimate the probable maximum precipitation under climate change situations, three types of inputs were required. These include observed data (predictand data), National Centre for Environmental Prediction (NCEP) reanalysis (predictor data), and CanESM2 model data from the AR5 for the historical and 2006-2100 for the future period. The CanESM2 is the SecondGeneration Canadian Earth System Model presented by the Canadian Centre for Climate Modeling and Analysis-CCCma (Mesbahzadeh et al. 2019). World Meteorological Organization (WMO, 1988) recommended 30 years or more as a standard reference for climate change and climate variability studies or trends in climatology. Future model change in climate is estimated using the climatological baseline period as a reference period (Houghton et al. 2001). Therefore, the longterm daily and hourly meteorological data from four rain gauge stations (Edareh Gorgan, Ghazmahalleh, Shastkelateh, Siahab) and one synoptic station (Gorgan) during the years 19882017 were applied to calculate $\mathrm{PMP}_{24}$ and the assessment of climate change impacts on $\mathrm{PMP}_{24}$. These data include three-hour dew point temperature, three-hour wind speed and direction at 10m elevations, three-hour and monthly air pressure, and 3 and 24-h precipitation. We gathered these data from the IRIMO (Islamic Republic of Iran Meteorological Organization, 2018). 
As mentioned above, to investigate climate change impact on PMPs, two series of daily predictors were used: the first, the 26 predictors of the National Center for Environmental

140 Prediction (NCEP), which will obtain from the statistical downscaling model (SDSM) website

141 (http://co-public.lboro.ac.uk/cocwd/SDSM/data.html); and second (b) the 26 predictors of

142 CanESM2, obtained from the Canadian website (http://www.cccsn.ec.gc.ca/?page=pred-

143 canesm2). These databases were specifically processed for SDSM. During the arrangement, the

144 NCEP predictors $\left(2.5^{\circ} \times 2.5^{\circ}\right)$ were first interpolated to the grid resolution of CanESM2 $\left(2.8^{\circ} \times 2.8^{\circ}\right)$

145 to remove the spatial incoordination. The predicted data were acquired by downscaling the

146 CanESM2 model under three RCP scenarios using the SDSM for each study station detailed in

147 section 2.4. Table 2 shows the Characteristics of the used climate model.

Table 2 The characteristics of CanESM2 model Arora et al. (2011)

\begin{tabular}{|c|c|c|c|c|c|c|}
\hline \multirow[t]{2}{*}{ Category } & \multirow[t]{2}{*}{ Model name } & \multicolumn{2}{|c|}{$\begin{array}{c}\text { Resolution } \\
\text { (Longitude } \times \text { Latitude) }\end{array}$} & \multirow{2}{*}{$\begin{array}{l}\text { Resolution } \\
\text { (Temporal) }\end{array}$} & \multirow[t]{2}{*}{ Institute } & \multirow[t]{2}{*}{ Scenarios } \\
\hline & & Atmosphere & Ocean & & & \\
\hline GCM & CanESM2 & $2.8^{\circ} \times 2.8^{\circ}$ & $1.41^{\circ} \times 0.94^{\circ}$ & Daily & $\begin{array}{c}\text { Canadian Center for Atmospheric } \\
\text { Research, Canada (CCCMA) }\end{array}$ & $\begin{array}{l}\text { RCP2.6, } \\
\text { RCP4.5, } \\
\text { RCP8.5 }\end{array}$ \\
\hline
\end{tabular}

\subsection{Physical approach}

There are two common physical approaches, namely the mountainous and convergence models,

151 to calculate PMP (Joos et al. 2005). The convergence model is based on physical storm

152 characteristics, i.e., dew point temperature, wind speed, wind direction, etc. The main steps to 153 calculate PMP using the convergence model are selecting severe storms, producing the depth-area154 duration (DAD) curves, moisture maximization, and wind maximization. The flowchart of the 155 methodology for the physical approach is mentioned in Fig 2. 


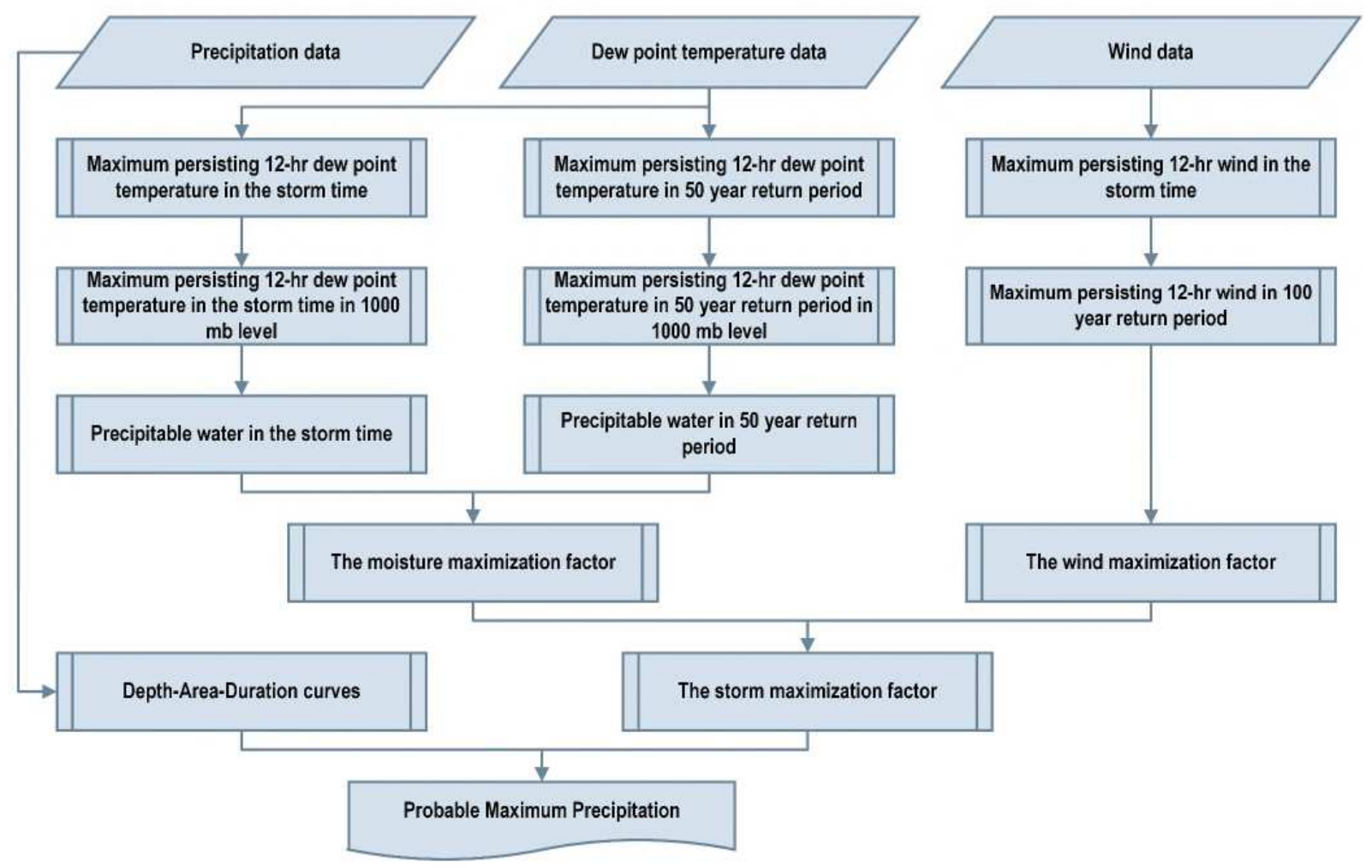

Fig. 2 The flowchart of the methodology for the physical approach (Source: Own Elaboration)

2.2.1. Selection of the most severe and widespread storms: A severe and widespread storm is a weather condition that produces precipitation in all basins and even around the basin. The most severe and widespread storms are selected based on maximum discharge and maximum 24-h rainfall data.

2.2.2. Producing DAD curves: The spatial distribution of rainfall rarely is uniform over a

161 region; in the centre of the storm, the depth of rainfall is maximum. DAD curves are essentially used to prove that as the distance from the centre of the storm increases, the depth of precipitation decreases. indeed, DAD curves are a suitable tool to demonstrate the spatial distribution of rainfall 164 over a basin or large region. Therefore, the procedure for obtaining DAD curves is described 165 below:

1) Determination the day of highest average rainfall depth, 
2) Producing isohyets maps which is one of the main steps in the preparation of DAD curves,

3) Calculation the enclosed area between two isohyets,

4) Calculation the incremental volume of rainfall through the multiplication of the area between the two isohyets and the average of the two isohyet values,

5) Calculation the total volume of rainfall,

6) Computation the average depth of rainfall over the study area through dividing the total volume of rainfall by the total area

7) Plotting the highest average depths for different areas as DAD curve (Raghunath, 2006). Using an analysis of the storms, DAD curves can be obtained. DAD curves are also applied to generalized relations for other areas or other basins with similar climate and topographic characteristics. The first step to developing the DAD curve is collecting the precipitation data for all storm areas.

2.2.3. Storm maximization: The storm maximization factor is calculated by the moisture maximization factor multiplied by the wind maximization factor. The moisture maximization method is an acceptable procedure to maximize the rainfall values associated with severe storms (Rakhecha and Singh, 2009). This method assumes that the atmospheric moisture would hypothetically rise to a high value that is regarded as the upper limit of moisture. The mentioned limit is estimated from historical records of dew point temperature. After selecting severe and widespread storms and calculating the average rainfall depth for the study area, it is necessary to calculate maximum humidity source in order to maximize selected storms. By converting mean monthly pressure data at each station to $1000 \mathrm{mb}$ pressure level, the effect of topography could be ignored. Dew point temperature and maximum 12-hour persisting condition at the stations during all storm events were computed and reduced to equivalent mean sea level (MSL, i.e., $1000 \mathrm{mb}$ pressure level). The moisture maximization factor $(F M)$ is calculated by Eq. (1). 


$$
\mathrm{FM}=\frac{\mathrm{W}_{\mathrm{m}}}{\mathrm{W}_{\mathrm{s}}}
$$

where $W_{m}$ is the maximum precipitable water in the 1000 to $200 \mathrm{mb}$ levels, which can be obtained based on the maximum 12-hour duration dew point with 50 -year return period. $W_{s}$ is the maximum precipitable water at 1000 to $200 \mathrm{mb}$ levels, which can be obtained based on maximum 12-hour duration dew point in a simultaneous period with the storm (WMO, 2009). Wind maximization is most commonly used in orographic regions when it appears that observed storm rainfall over a mountain range might vary in proportion to the speed of the moisture-bearing wind blowing against the range. The wind maximization ratio is simply the maximum average wind speed ratio for some specific duration and critical direction obtained from a long record of observations, e.g., 50 or 100-years, to the observed maximum average wind speed for the same duration and direction in the storm being maximized. The wind speed maximization factor $(M W)$ is defined by Eq. (2).

$$
\mathrm{MW}=\frac{\mathrm{MW}_{1}}{\mathrm{MW}_{2}}
$$

where $M W_{1}$ and $M W_{2}$ are the maximum wind speed with 100-year return period and the maximum persisting 12-hour wind speed during the storm, respectively (WMO, 2009). Finally, PMP is determined by the precipitation depth $(R)$ multiplied by moisture maximization and wind maximization factors based on Eq. (3).

$$
P M P=F M \times M W \times R
$$

\subsection{RCP Scenarios and the statistical downscaling model (SDSM)}

According to the Fifth Assessment Report of the Intergovernmental Panel on Climate Change (AR5), the future climate condition at the global scale is simulated using general circulation models (GCM). Based on the AR5 models, that was prepared using the output of the CMIP5 
models, the surface temperature at the end of the $21^{\text {st }}$ century will increase more than $1.5^{\circ} \mathrm{C}$ (IPCC, 2014). The AR5 models use representative concentration pathways (RCPs) emission scenarios that have four pathways including RCP2.6, RCP4.5, RCP6, and RCP8.5, based on their radiative forcing values in 2100 (Van Vuuren et al. 2011; Moss et al. 2010). For instance, RCP2.6 is a pathway where radiative forcing peaks at about $3 \mathrm{~W} \mathrm{~m}^{-2}$ before 2100 and then reduces. The general circulation model (GCM) is the most suitable method for assessing the impacts of climate change on global environmental systems (Sehgal et al. 2018) but due to their coarse grid spacing (about $10 \mathrm{~km}$ ), the application of these models is not appropriate at regional or local scales (Hay et al. 2000; Gebremeskel et al. 2005). Downscaling is the most important and suitable tool for linking the local/regional scale and GCM. As a whole, there are two statistical and dynamic methods for downscaling GCM (Salehnia et al. 2019). In the SDSM, as a widely used statistical downscaling method, the empirical/statistical relationship between large-scale and local/regional climate variables is established (Wilby et al. 2002; Palatella et al. 2010; Huang et al. 2011).

The SDSM, which is developed by Wilby et al. (2002), is a useful tool that combined multiple linear regression and stochastic weather generators (Dehghan et al. 2020), and users are permitted to simulate, series of daily climatic data for present and future periods by obtaining statistical parameters from observed data series (Gagnon et al. 2005). The stochastic component of SDSM allows the generation of 100 daily simulations that have good correlation with observed data in the validation step (Gagnon et al. 2005). Based on the type and nature of the input data, SDSM is calibrated under conditional and unconditional process. Hence, precipitation and temperature are conditional and unconditional processes, respectively (Gebrechorkos et al. 2019). The method has four main steps including the screening of NCEP predictors, calibration, validation, and climate scenario generation under the RCP scenarios for future time horizons. The flowchart and detail of 
methodology for downscaling and Climate scenario generation via SDSM are described in Dehghan et al. (2020).

2.3.1. The screening of NCEP predictors: Recognizing empirical relationships between NCEP predictors and predictands is important to all statistical downscaling methods and is often 237 the most time-consuming step in the process. The purpose of this step is to help the user in the selection of suitable downscaling predictor variables for model calibration (Wilby and Dawson 2007). In this step, due to the correlation matrix, partial correlation and P-value, NCEP predictors are selected based on strength of each predictor - predictand relationship. These indicators have used in Dehghan et al. (2020), Al-Mukhtar and Qasim (2019), and Mahmood and Babel (2014).

2.3.2. Calibration and Validation: In this step, monthly regression models are produced using selected NCEP predictor variables and a simulation is executed using a part of input data series.

244 the quality of model calibration is reported using monthly average of coefficient of determination 245 ( $\mathrm{R}^{2}$; Eq. 4) and values of standard error (SE; Eq. 5). The other parts of input data series are 246 simulated with the calibrated regression models. Then, the predicted and observed monthly means 247 and variances are compared using $\mathrm{R}^{2}$ and F-tests.

$$
\begin{aligned}
\mathrm{R}^{2}= & \frac{\left[\sum_{\mathrm{i}=1}^{\mathrm{n}}\left[\mathrm{O}_{\mathrm{i}}-\overline{\mathrm{O}}_{\mathrm{i}}\right] \cdot\left[\mathrm{P}_{\mathrm{i}}-\overline{\mathrm{P}}_{\mathrm{i}}\right]\right]^{2}}{\sum_{\mathrm{i}=1}^{\mathrm{n}}\left[\mathrm{O}_{\mathrm{i}}-\overline{\mathrm{O}}_{\mathrm{i}}\right]^{2} \cdot \sum_{\mathrm{i}=1}^{\mathrm{n}}\left[\mathrm{P}_{\mathrm{i}}-\overline{\mathrm{P}}_{\mathrm{i}}\right]^{2}} \\
\mathrm{SE} & =\frac{\sigma}{\sqrt{\mathrm{n}}}
\end{aligned}
$$

Where $O_{i}$ and $P_{i}$ were the observed and predicted values, $\overline{\mathrm{O}}_{\mathrm{i}}$ and $\overline{\mathrm{P}}_{\mathrm{i}}$ were the average of 249 observed and predicted values, $\sigma$ was sample standard deviation, and $n$ is the number of samples. 
2.3.3. Climate scenario generation: After validation, the daily time series of dew point temperature and precipitation were generated for future time horizons including under RCP 252 scenarios.

\subsection{Performance criteria}

254 The performance and accuracy of the model and compare the generated future climatic data with 255 observed data, were judged by four performance criteria including coefficient of determination 256 "R 2 ", root mean square error "RMSE” (MacLean, 2005), mean absolute error "MAE" (MacLean, 257 2005), and Nash and Sutcliffe efficiency "NSE" (Nash and Sutcliffe, 1970) that are defined as:

$$
\begin{aligned}
& \text { RMSE }=\sqrt{\frac{\sum_{i=1}^{n}\left[\mathrm{O}_{\mathrm{i}}-\overline{\mathrm{P}}_{\mathrm{i}}\right]^{2}}{\mathrm{n}}} \\
& \mathrm{MAE}=\frac{\sum_{\mathrm{i}=1}^{\mathrm{n}}\left|\mathrm{O}_{\mathrm{i}}-\mathrm{P}_{\mathrm{i}}\right|^{2}}{\mathrm{n}} \\
& \mathrm{NSE}=1-\frac{\sum_{\mathrm{i}=1}^{\mathrm{n}}\left[\mathrm{O}_{\mathrm{i}}-\mathrm{P}_{\mathrm{i}}\right]^{2}}{\sum_{\mathrm{i}=1}^{\mathrm{n}}\left[\mathrm{O}_{\mathrm{i}}-\overline{\mathrm{O}}_{\mathrm{i}}\right]^{2}}
\end{aligned}
$$

$R^{2}$ varies between 0 and 1 and a value of $R^{2}$ closer to 1 shows better performance. $R M S E$ reveals

259 the actual division among the predicted and observed values. Also, RMSE value closer to or equal 260 to zero, and smaller value of $M A E$ reveal a more accurate performance. The $N S E$ values ranged 261 from $-\infty$ to 1 and the value of 1 shows perfect fit.

\section{Results and Discussion}

\subsection{SDSM Calibration and Validation}

As mentioned in the previous sections, SDSM was applied to downscale rainfall and dew temperature from GCMs. To this end, the precipitation data of five stations including Edareh gorgan, Ghazmahalleh, Shastkelateh, Gorgan, and Siahab, and the dew point temperature data of one synoptic station named Gorgan were used as predictand data. During the screening process, 

matrix, and P-value, for dew point temperature and rainfall with a confidence level of $95 \%$. Table performance of SDSM during calibration in the study stations.

Table 3 Selected predictors for dew point temperature and rainfall during screening of predictors step, in the Qare-Su basin

\begin{tabular}{ccc}
\hline Variable & Stations & The selected NCEP predictors** \\
\hline Rainfall & Edareh gorgan & p5_v, shum \\
& Ghazmahalleh & p8_z, p850 \\
& Shastkelateh & p500, p8_f \\
& Gorgan & p850,p_zh \\
& Siahab & mslp, p_u,p5_v \\
\hline Dew point temperature & Gorgan & p_u, p5_f, shum, temp
\end{tabular}

** p5_v: Meridional velocity component at $500 \mathrm{hPa}$, shum: Near surface specific humidity, p8_z: Vorticity at 850 $\mathrm{hPa}$, p850: $850 \mathrm{hPa}$ geopotential height, p500: $500 \mathrm{hPa}$ geopotential height, p8_f: Geostrophic airflow velocity at 850 hPa, p_zh: Divergence near the surface, mslp: Mean sea level pressure, $\mathbf{p}_{-} \mathbf{u}$ : Zonal velocity component near the surface, p5_f: Geostrophic airflow velocity at $500 \mathrm{hPa}$, temp: Near surface air temperature

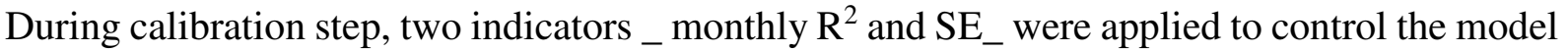
performance and efficiency. Monthly $\mathrm{R}^{2}$ values were calculated for each station and vary from 0.275 to 0.37 for rainfall (Table 4); also, the monthly $R^{2}$ value was 0.7 for dew point temperature.

The maximum and minimum values of SE, for rainfall, were 0.39 and 0.354 , which is related to Shastkalateh and Gorgan stations, respectively. The SE value for dew point temperature was 1.6. 
Table 4 The results of model calibration

\begin{tabular}{ccccc}
\hline Variable & Stations & Calibration period & Monthly Average of & SE \\
& & & $\mathbf{R}^{\mathbf{2}}$ & \\
\hline & Edareh gorgan & $1988-2002$ & 0.313 & 0.365 \\
& Ghazmahalleh & $1988-2002$ & 0.37 & 0.385 \\
Rainfall & Shastkelateh & $1988-2002$ & 0.29 & 0.354 \\
& Gorgan & $1988-2002$ & 0.275 & 0.39 \\
& Siahab & $1988-2002$ & 0.37 & 0.37 \\
\hline Dew point temperature & Gorgan & $1988-2002$ & 0.7 & 1.6 \\
\hline
\end{tabular}

284

Based on Table 4, monthly average $\mathrm{R}^{2}$ for the rainfall data in the validation stage was lower than the dew point temperature data and the efficiency of the SDSM model in downscaling the rainfall data for all stations are similar.

After successful validation, the daily time series of dew point temperature and rainfall were generated using SDSM model and the outputs of CanESM2 for two-time horizons including the near-future (2019-2048), and the far-future (2049-2078), under three RCP scenarios (RCP2.6, RCP4.5, and RCP8.5). Table 5 summarize the statistical comparison of the projection data and observed data in calibration and validation steps. The NSE and $\mathrm{R}^{2}$ values show the high accuracy of downscaling dew point temperature and rainfall data. Therefore, SDSM model can be used to estimate future values of rainfall and dew point temperature. 
Table 5 Model performance evaluation in validation and projection of the baseline period

\begin{tabular}{|c|c|c|c|c|c|c|c|c|c|c|c|}
\hline \multirow{3}{*}{ Variable } & \multirow{3}{*}{ Stations } & \multicolumn{5}{|c|}{ Validation } & \multicolumn{5}{|c|}{ Projection } \\
\hline & & \multicolumn{3}{|c|}{ Significant } & \multicolumn{7}{|c|}{ Significant } \\
\hline & & $\mathbf{R}^{2}$ & $\begin{array}{c}\text { level of } F \\
\text { test }\end{array}$ & RMSE & MAE & NSE & $\mathbf{R}^{2}$ & $\begin{array}{c}\text { level of } F \\
\text { test }\end{array}$ & RMSE & MAE & NSE \\
\hline \multirow{5}{*}{ Rainfall } & Edareh gorgan & 0.8 & $4.5 \times 10^{-14}$ & 0.8 & 0.6 & 0.7 & 0.6 & 0.004 & 1.4 & 1.1 & 0.08 \\
\hline & Ghazmahalleh & 0.8 & $2.4 \times 10^{-16}$ & 1.3 & 1.0 & 0.3 & 0.4 & 0.02 & 1.9 & 1.7 & 0.02 \\
\hline & Shastkelateh & 0.8 & $6.5 \times 10^{-15}$ & 1.2 & 0.9 & 0.5 & 0.3 & 0.09 & 2.09 & 2.3 & 0.06 \\
\hline & Gorgan & 0.8 & $1 \times 10^{-4}$ & 1.1 & 0.8 & 0.4 & 0.5 & 0.008 & 1.5 & 1.6 & 0.07 \\
\hline & Siahab & 0.8 & $2.1 \times 10^{-12}$ & 1.3 & 1.2 & 0.5 & 0.3 & 0.07 & 2.49 & 2.1 & 0.05 \\
\hline $\begin{array}{l}\text { Dew point } \\
\text { temperature }\end{array}$ & Gorgan & 0.9 & $7.5 \times 10^{-14}$ & 0.6 & 0.5 & 0.9 & 0.9 & $9.8 \times 10^{-14}$ & 1.1 & 0.8 & 0.9 \\
\hline
\end{tabular}

According to Fig. 3-a, which shows the variation of the monthly and seasonal dew point temperature of Gorgan station during future periods, in the near-future period, for RCP2.6 and 4.5, monthly average dewpoint temperature decreased from March to May, and for RCP8.5 fell in April

298 and May. in contrast, other months show dew point temperature increases in all scenarios. The 299 maximum and minimum percent of increasing dew point temperature is equal to $67 \%$ related in 300 January under RCP8.5 and 1\% related in June under RCP4.5. The seasonal average dew point 301 temperature during the near-future period increased in winter, summer, and autumn under three 302 RCP scenarios. The average observed dew point temperature was more significant in the spring 303 than the average future dew point temperature under three RCP scenarios. The maximum dew 304 point temperature increase was equal to $15 \%$ in the seasonal time scale, related in autumn under $305 \mathrm{RCP} 4.5$ and RCP 8.5. In addition, the minimum dew point temperature increase was equivalent to $30610 \%$, related in summer under RCP4.5. During the far-future period, monthly average dew point 307 temperature decreased about $1 \%$ in April under RCP4.5. In other months and RCPs, monthly 308 average dew point temperature increased between 0.3 to $67 \%$, related in April and May under 
RCP2.6 and January under RCP 8.5, respectively. The maximum dew point temperature increase in the seasonal time scale was equal to $37 \%$, related in winter under RCP8.5. Also, the minimum dew point temperature increase was equal to $3 \%$, related in spring under RCP4.5.

The variation of the monthly and seasonal rainfall of Gorgan station during the future periods shows in Fig. 3-b. Overall, the monthly variation of rainfall in Gorgan station in the near-future was decreased except August and September under RCP 4.5 and September under RCP8.5. These values were 11,1 , and $8 \%$, respectively. Also, the maximum values of monthly decrease were 30 , 60, and 65\% in RCP2.6, RCP4.5, and RCP8.5 which are related in June, July, and April, respectively. The minimum rainfall decreases were 4\% under RCP 2.6 (November) and 1\% under RCP4.5 (April) and RCP8.5 (August). The seasonal average rainfall during this period decreased for all seasons and all RCPs. Besides, in the far-future period, the values of monthly rainfall decreases were 38, 54, and 65\% related in May, December, and April, under RCP2.6, RCP4.5, and RCP8.5, respectively. Also, these seasonal values decreased under all RCPs.

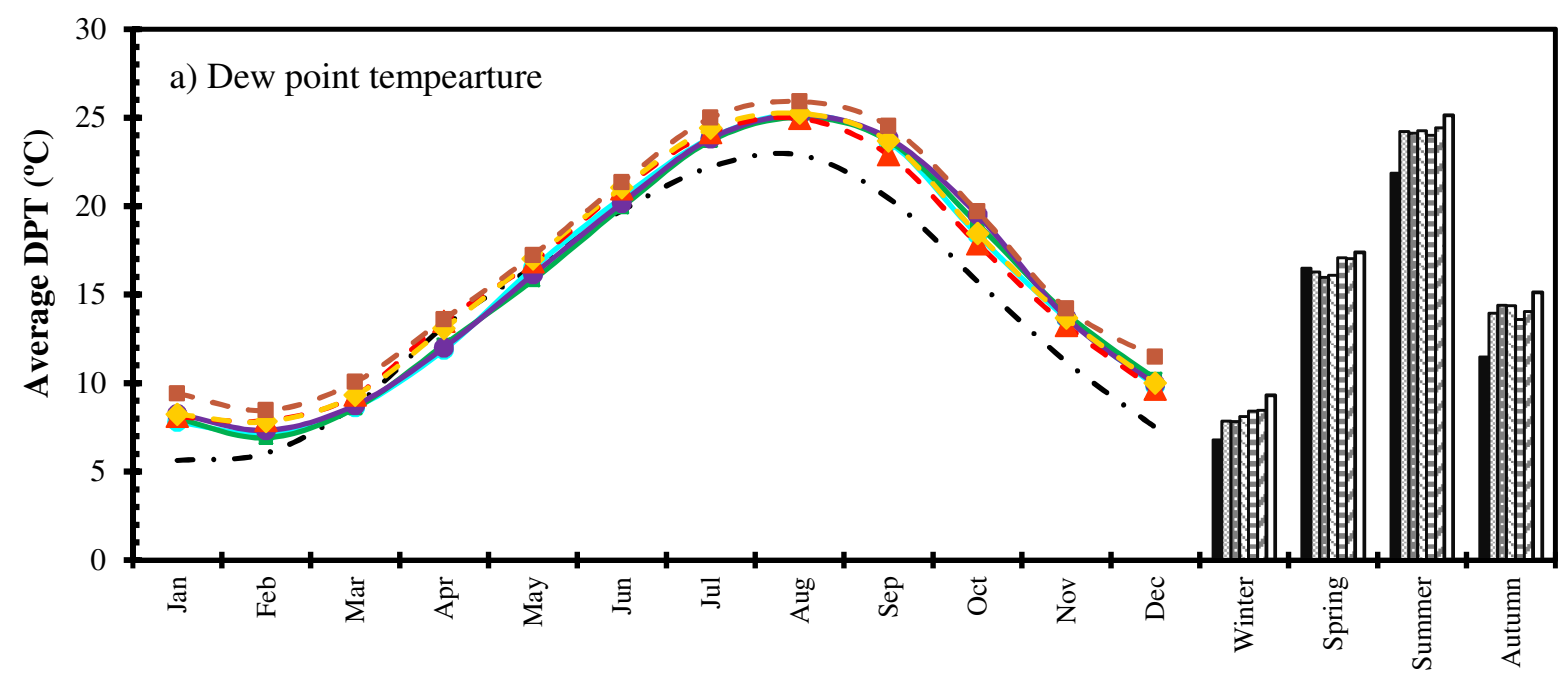




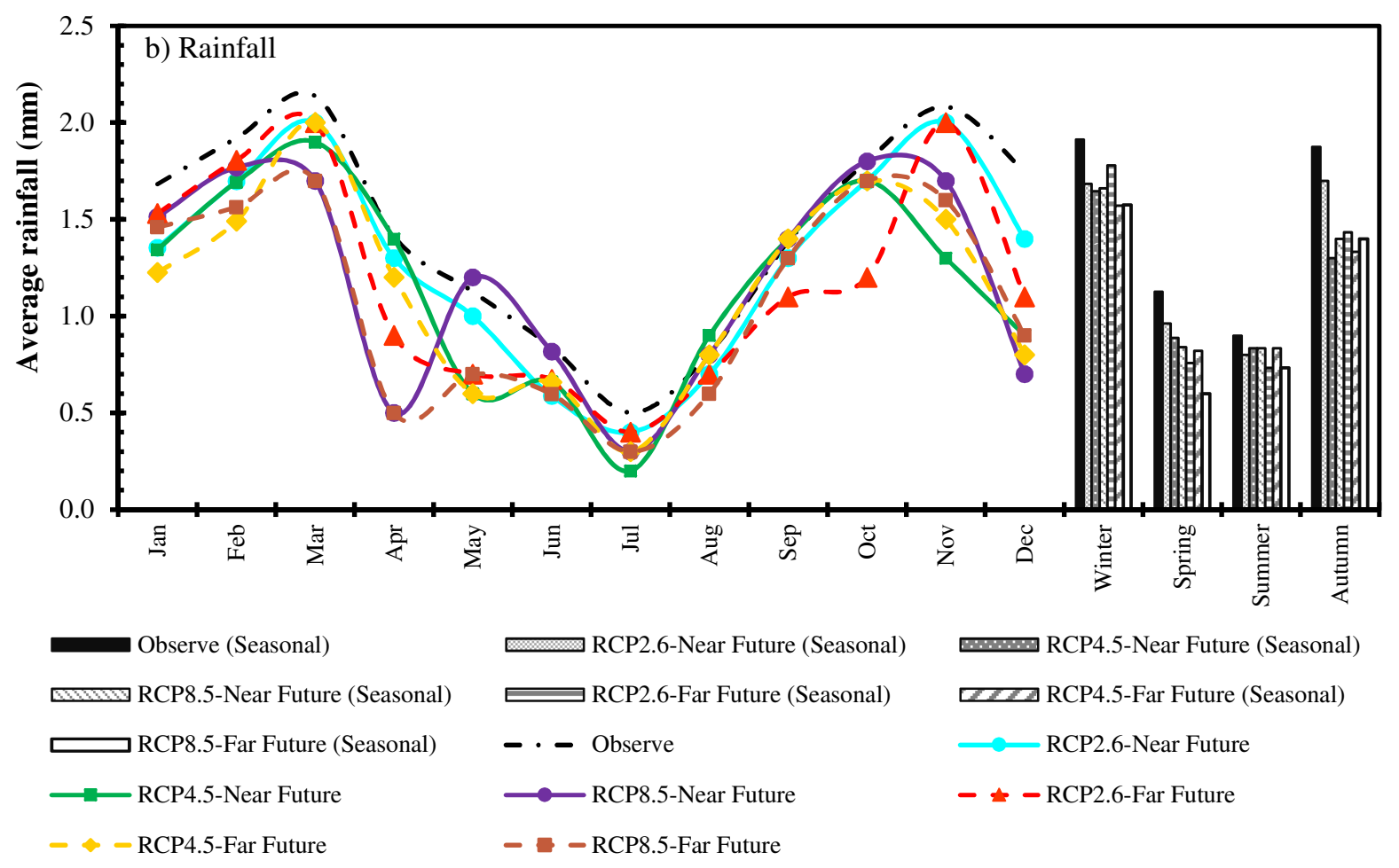

Fig. 3 The variation of the monthly and seasonal (a) dew point temperature and (b) rainfall of Gorgan station during future periods

\subsection{PMP Calculation Using Physical Method}

The observed and the future rainfall data were used to determine the most severe and widespread storms. Based on these data, thirteen storms were selected as the most severe and widespread storms during the baseline, near, and far-future periods (Table 6).

After determination of the most severe and widespread storm dates, in order to analyze and the spatial distribution of rainfall and drawing the isohyet maps, rainfall gradient (elevation-rainfall relationship) was investigated. Investigation of rainfall - elevation relationship showed that there is no significant correlation between rainfall and elevation at the 5\% level of significance. Therefore, isohyet maps with $10 \mathrm{~mm}$ interval for each storm were developed using inverse distance weighting (IDW) method through ArcMap version 10.5; also, the enclosed area between two 
332 isohyets was measured. Finally, DAD curves for each storm during baseline and two future periods

333 under three RCP scenarios were generated. Table 7 shows the required calculations to produce

334 DAD curves.

335 Table 6 Dates of 24-h duration severe and widespread storms in the study area during the baseline, the near and the 336 far-future periods under the RCP scenarios

\begin{tabular}{lccc}
\hline & Baseline (1988-2017) & Near-future (2019-2048) & Far-future (2049-2078) \\
\cline { 2 - 4 } No. & Date of occurrence & Date of occurrence & Date of occurrence \\
$(\mathbf{m m} / \mathbf{d d} / \mathbf{y y y y})$ & $(\mathbf{m m} / \mathbf{d d} / \mathbf{y y y y})$ & $09 / 30 / 2064$ \\
\hline 1 & $11 / 12 / 1995$ & $09 / 27 / 2045$ & $11 / 11 / 2062$ \\
2 & $10 / 29 / 1993$ & $04 / 25 / 2044$ & $10 / 06 / 2059$ \\
3 & $10 / 09 / 2006$ & $05 / 11 / 2025$ & $10 / 06 / 2057$ \\
4 & $07 / 17 / 2012$ & $03 / 14 / 2023$ & $10 / 23 / 2060$ \\
5 & $01 / 11 / 2013$ & $05 / 11 / 2040$ & $01 / 30 / 2051$ \\
6 & $09 / 29 / 2008$ & $09 / 14 / 2019$ & $03 / 10 / 2066$ \\
7 & $09 / 27 / 1995$ & $05 / 19 / 2031$ & $10 / 24 / 2078$ \\
8 & $10 / 13 / 1991$ & $04 / 26 / 2027$ & $03 / 30 / 2065$ \\
9 & $10 / 21 / 2011$ & $02 / 27 / 2040$ & $10 / 24 / 2074$ \\
10 & $10 / 13 / 2012$ & $05 / 09 / 2034$ & $04 / 21 / 2053$ \\
11 & $08 / 16 / 1993$ & $02 / 02 / 2026$ & $02 / 05 / 2051$ \\
12 & $12 / 26 / 2005$ & $10 / 21 / 2048$ & $10 / 05 / 2059$ \\
13 & $06 / 04 / 2014$ & $09 / 12 / 2025$ & \\
\hline
\end{tabular}


Table 7 The average of 24-h rainfall for the storm of 12 September 2025 in the study area

\begin{tabular}{|c|c|c|c|c|c|c|}
\hline $\begin{array}{c}\text { Limit of } \\
\text { isohyet lines } \\
\text { (mm) }\end{array}$ & $\begin{array}{c}\text { Average of } \\
\text { isohyet (mm) }\end{array}$ & $\begin{array}{l}\text { Area } \\
\left(\mathbf{k m}^{2}\right)\end{array}$ & $\begin{array}{l}\text { Cumulative } \\
\text { area }\left(\mathbf{k m}^{2}\right)\end{array}$ & $\begin{array}{c}\text { Volume of the } \\
\text { rainfall } \\
\left(1000 \mathrm{~m}^{3}\right)\end{array}$ & $\begin{array}{c}\text { Cumulative volume } \\
\text { of the rainfall } \\
\left(1000 \mathrm{~m}^{3}\right)\end{array}$ & $\begin{array}{c}\text { Average of } \\
\text { maximum rainfal } \\
(\mathrm{mm})\end{array}$ \\
\hline $90-80$ & 85 & 14.11 & 14.11 & 1199.4 & 1199.4 & 85.0 \\
\hline $80-70$ & 75 & 26.41 & 40.5 & 1980.8 & 3180.2 & 78.5 \\
\hline $70-60$ & 65 & 36.41 & 76.9 & 2366.7 & 5546.8 & 72.1 \\
\hline $60-50$ & 55 & 58.31 & 135.2 & 3207.1 & 8753.9 & 64.7 \\
\hline $50-40$ & 45 & 123.31 & 258.6 & 5549.0 & 14302.8 & 55.3 \\
\hline $40-30$ & 35 & 227.12 & 485.7 & 7949.2 & 22252.0 & 45.8 \\
\hline $30-20$ & 25 & 456.91 & 942.6 & 11422.8 & 33674.8 & 35.7 \\
\hline $30-10$ & 15 & 464.21 & 1406.8 & 6963.2 & 40637.9 & 28.9 \\
\hline $10-0$ & 5 & 353.21 & 1760.0 & 1766.1 & 42404.0 & 24.1 \\
\hline
\end{tabular}

339 DAD's envelope curves were produced to select the highest depths of rainfall in each scenario 340 and each period. Fig. 4 shows the DAD curves for storms chosen in the near-future period under 341 RCP8.5 Scenario. Based on this figure, the storm of September 2025 was the most severe and 342 widespread one which was considered as the envelope curve. In this curve, maximum rainfall value 343 was $85 \mathrm{~mm}$ which indicated the storm center. As the distance from the center of the storm 344 increases, the depth of precipitation decreases, because the area affected by the storm increases. 


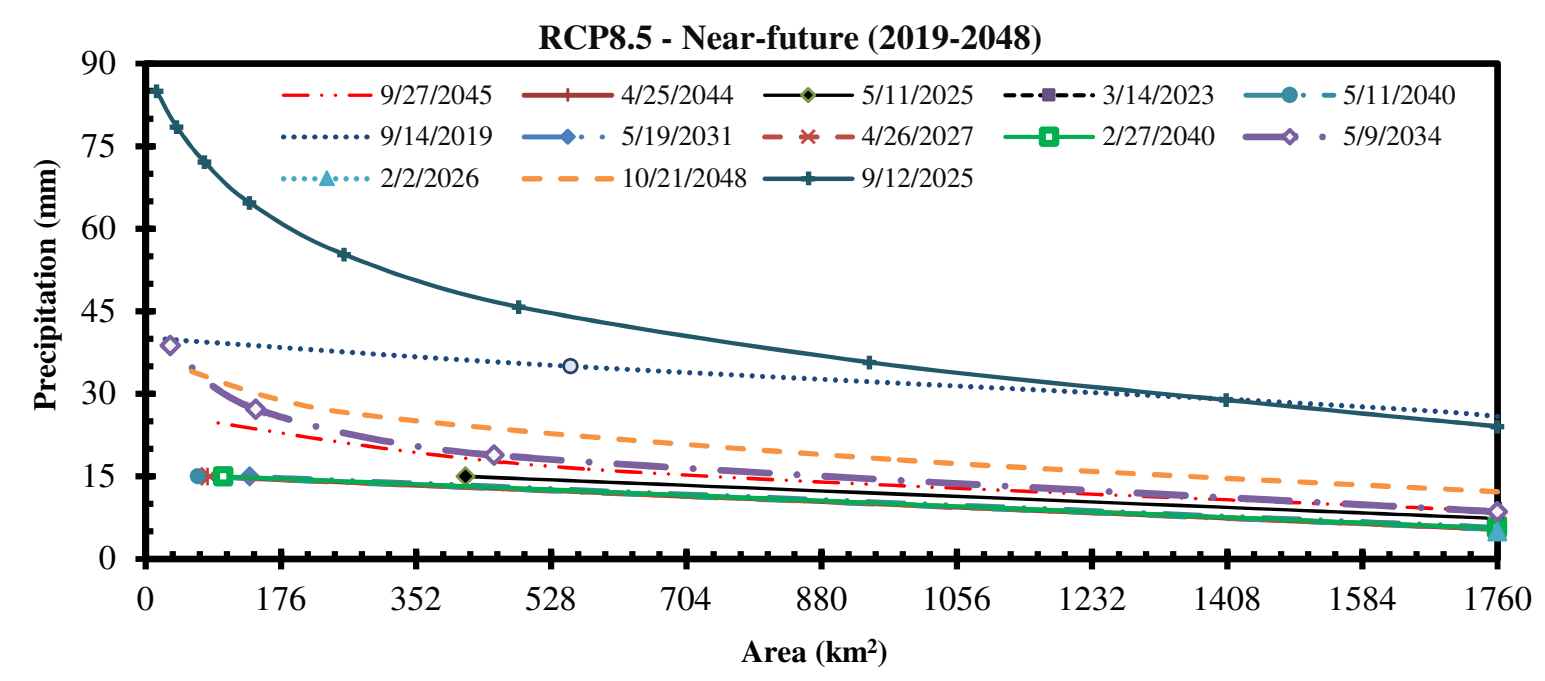

Fig. 4 Depth-Area-Duration curves for selected storms in near-future period under RCP8.5 scenario

The moisture maximization factor $\left(W_{m}\right)$ was calculated through maximization of dewpoint temperature data with 50-year return period using Tephigram (Skew-T diagram). Besides, the wind maximization factor $\left(M W_{l}\right)$ was estimated using wind speed data of Gorgan station with 100-year return period. Because wind is a vector variable and projection of its behavior for future periods using statistical methods is associated with many uncertainties, wind maximization factor of baseline period is used for maximizing storms in the future periods. After the calculation of moisture and wind maximization factors, PMP was calculated using equation 5. The amounts of moisture and wind maximization factors are shown in Table 8.

Fig. 5 shows the PMP values for the baseline and the future periods under the RCP scenarios. The PMP value for the baseline period is $143 \mathrm{~mm}$ (Afzali-Gorouh et al. 2018). Under changing climatic conditions, the PMP values will decrease. For the near-future, the PMP values are 98, 105, and $109 \mathrm{~mm}$ under the RCP2.6, RCP4.5, and RCP8.5, respectively. For the far-future, these values are 129, 122, and $126 \mathrm{~mm}$ under RCP2.6, RCP4.5, and RCP8.5, respectively. The results showed that PMP values would decrease in future periods, but the near-future reduces more than the far-future. 
Table 8 The maximization factors, PMP values and percentage of differences between the baseline and the future

361 periods under the RCP scenarios

\begin{tabular}{|c|c|c|c|c|c|c|c|c|}
\hline \multirow{2}{*}{ Period } & \multirow{2}{*}{ Scenario } & \multirow{2}{*}{$\begin{array}{c}\text { date of } \\
\text { occurrence } \\
(\mathrm{mm} / \mathrm{dd} / \mathrm{yyyy})\end{array}$} & \multicolumn{2}{|c|}{$\begin{array}{c}\text { Maximum persisting } \\
\text { 12-hour dew point in } \\
1000 \mathrm{mb} \text { level }\left({ }^{\circ} \mathrm{C}\right)\end{array}$} & \multicolumn{2}{|c|}{$\begin{array}{l}\text { Maximum persisting } \\
\text { 12-hr wind (Knot) }\end{array}$} & \multicolumn{2}{|c|}{$\begin{array}{c}\text { Maximization } \\
\text { factor }\end{array}$} \\
\hline & & & $\begin{array}{l}\text { In the } \\
\text { storm } \\
\text { time }\end{array}$ & $\begin{array}{l}\text { 50-year } \\
\text { return } \\
\text { period }\end{array}$ & $\begin{array}{l}\text { In the } \\
\text { storm } \\
\text { time }\end{array}$ & $\begin{array}{l}\text { 100-year } \\
\text { return } \\
\text { period }\end{array}$ & FM & MW \\
\hline $1988-2017$ & Baseline & $10 / 29 / 1993$ & 14.1 & 20.6 & 7 & 10.1 & 1.4 & 1.4 \\
\hline \multirow{4}{*}{ 2019-2048 } & RCP2.6 & $02 / 02 / 2026$ & 3.7 & 14.3 & 9.7 & 19.2 & 2.1 & 1.98 \\
\hline & RCP4.5 & $02 / 02 / 2026$ & 5.8 & 15.3 & 9.7 & 19.2 & 1.8 & 1.98 \\
\hline & RCP8.5 & $02 / 02 / 2026$ & 4.6 & 14.9 & 9.7 & 19.2 & 1.9 & 1.98 \\
\hline & RCP2.6 & $01 / 30 / 2051$ & 8.7 & 17.2 & 8.3 & 16.6 & 1.8 & 2.0 \\
\hline \multirow[t]{2}{*}{$2049-2078$} & RCP4.5 & $01 / 30 / 2051$ & 10.8 & 17.8 & 8.3 & 16.6 & 1.6 & 2.0 \\
\hline & RCP8.5 & $01 / 30 / 2051$ & 8.9 & 18.0 & 8.3 & 16.6 & 1.9 & 2.0 \\
\hline
\end{tabular}

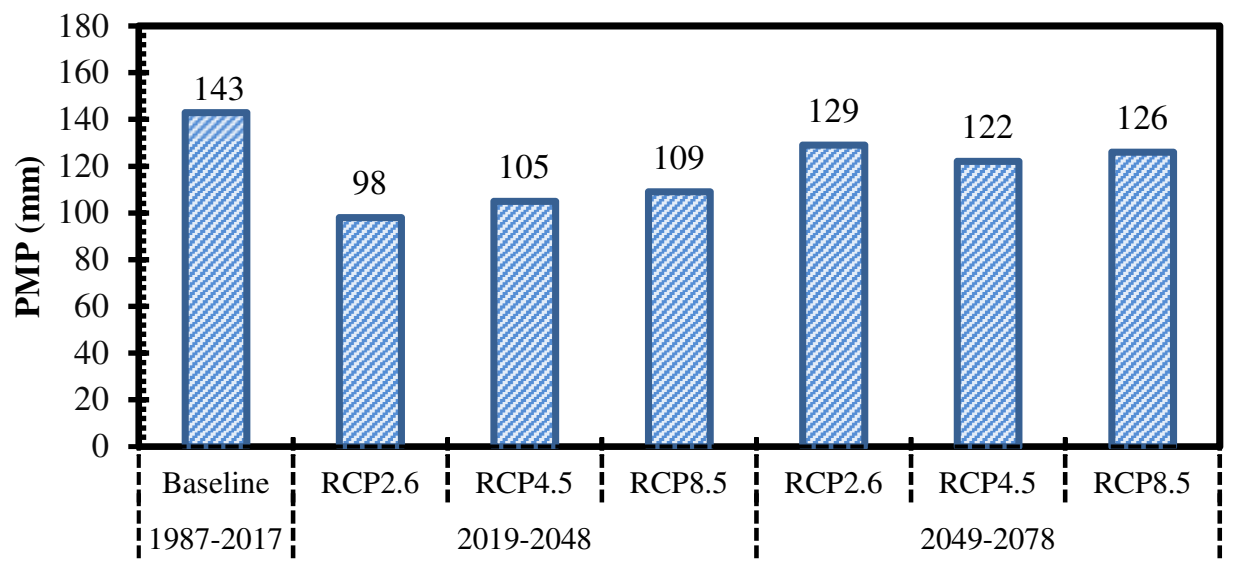

Fig. 5 The PMP values and percentage of differences between the baseline and the future periods under the RCP scenarios 
The percentage of PMP differences between the baseline and the near-future period will be 21, related in RCP8.5 and RCP2.6 during near-future period.

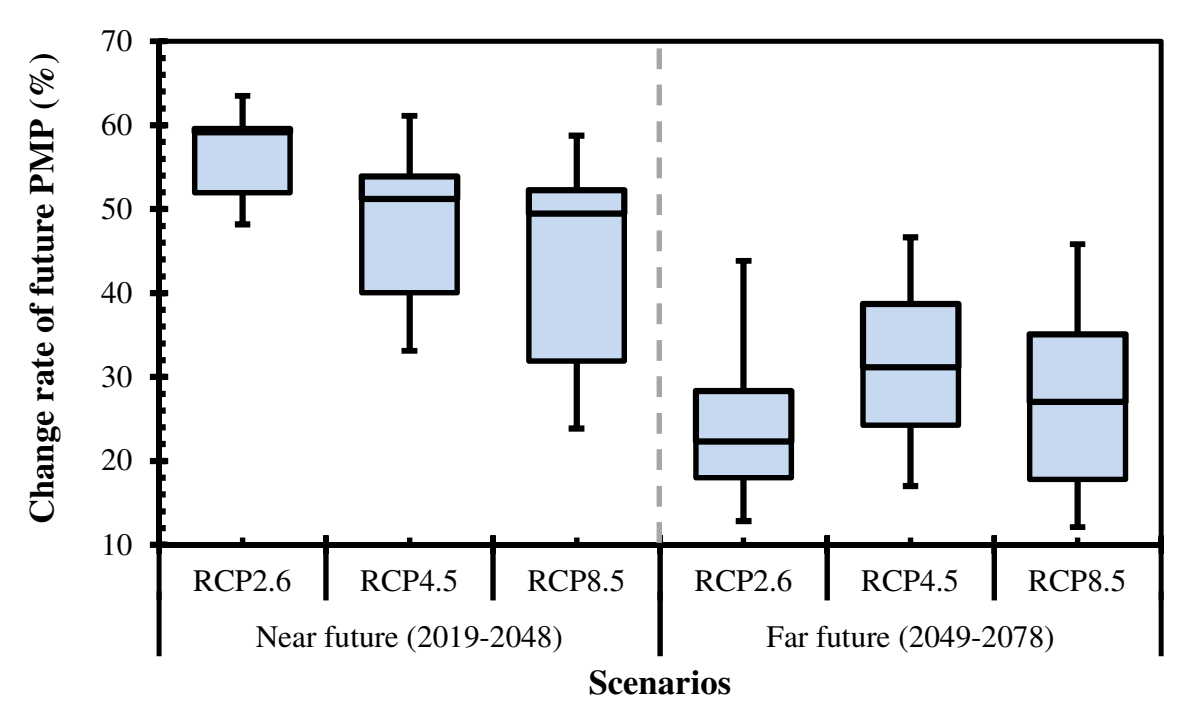

Fig. 6 The change rate of future $\mathrm{PMP}_{24}$ in the future periods under RCP scenarios 26, and $24 \%$ in RCP2.6, RCP4.5, and RCP8.5 scenarios, respectively. These mentioned values will be 10,15 , and $12 \%$ in the far-future period. These values showed that the PMP values would decrease in future periods under climate change conditions. According to Fig. 6, the maximum and minimum PMP24 changing rate during near-future period under RCP2.6, RCP4.5, and RCP8.5 scenarios are equal to $64,62,59$, and 48,33 , and 24 percent. These values for far-future period are $45,47,46$, and 13,17 , and 12 , respectively. The maximum and minimum ranges of variation are experienced heavy floods and rainfalls since it is located beside the Caspian Sea and the air masses bring moisture from the Caspian Sea to this area. Therefore, the impact of climate change on 24-h PMP in this basin was studied using outputs of the general circulation model CanESM2 under three RCP scenarios utilizing the statistical downscaling model (SDSM). 
Hence, SDSM was successfully calibrated during the period of 1988 to 2002 and validated during the period of 2003 to 2018 to investigate future changes in $\mathrm{PMP}_{24}$ in the Qareh-Su basin 380 for the near (2019-2048) and far (2049-2078) future periods under the RCP2.6, RCP4.5, and RCP8.5 scenarios, compared to the baseline period (1988-2018). dew point temperature (one synoptic station) data as well as the presence of several severe and widespread storms in the study area, the physical approach was considered to calculate the $\mathrm{PMP}_{24}$. The results obtained from this approach showed that PMPs would decrease in future periods under all RCP scenarios. The PMP values for the near-future period compared to the baseline period under RCP2.6, RCP4.5, and RCP8.5 scenarios will reduce by 31, 26, and 24\%, respectively. For the far-future, under three scenarios will decrease by 10,15 , and $12 \%$, respectively, compared to 389 the baseline period.

390 Finally, it is recommended that the results of PMP values be estimated and compared with the 391 outputs of other climate models and other downscaling methods.

\section{References}

393 Afzali-Gorouh Z, Bakhtiari B, Qaderi K (2018) Probable maximum precipitation estimation in a 394 humid climate. Nat Hazards Earth Syst Sci 18(11): 3109-3119. https://nhess.copernicus.org/articles/18/3109/2018/

Al-Mukhtar M, Qasim M (2019) Future predictions of precipitation and temperature in Iraq using the statistical downscaling model. Arab J Geosci 12(2): 25. https://doi.org/10.1007/s12517- 
Arora V K, Scinocca J F, Boer G J, Christian J R, Denman K L, Flato G M, .. \& Merryfield W J (2011) Carbon emission limits required to satisfy future representative concentration pathways of greenhouse gases. Geophys Res Lett 38(5). https://doi.org/10.1029/2010GL046270.

Beauchamp J, Leconte R, Trudel M, Brissette F (2013) Estimation of the summer-fall PMP and PMF of a northern watershed under a changed climate. Water Resour Res 49: 3852-3862. https://doi.org/10.1002/wrcr.20336

Casas M C, Rodriguez R, Prohom M, Gazquez A, Redano A (2011) Estimation of probable maximum precipitation in Barcelona (Spain). Int $\mathrm{J}$ Climatol 31: 1322-1327. https://doi.org/10.1002/joc.2149

Dehghan Sh, Salehnia N, Sayari N, Bakhtiari, B (2020) Prediction of meteorological drought in arid and semi-arid regions using PDSI and SDSM: a case study in Fars Province, Iran. Arid Land 12(2): 318-330. https://doi.org/10.1007/s40333-020-0095-5

Deshpande N R, Kulkarni B D, Verma A K, Mandal B N (2008) Extreme rainfall analysis and estimation of probable maximum precipitation (PMP) by statistical methods over the Indus river basin in India. J Spat Hydrol 8: 22-36.

Douglas E M, Barros A P B (2003) Probable maximum precipitation estimation using multifractals: application in the Eastern United States. J Hydrometeorol, 4: 1012-1024, https://doi.org/10.1175/1525-7541(2003)004<1012: PMPEUM>2.0.CO;2.

Fattahi E, Noorian A M, Noohi K (2010) Comparison of physical and statistical methods for estimating probable maximum precipitation in south-western basins of Iran. DESERT 15: 127132.

Gagnon S, Singh B, Rousselle J, Roy L (2005) An application of the statistical downscaling model (SDSM) to simulate climatic data for streamflow modelling in Québec. Can Water Resour J 30(4): 297-314. https://doi.org/10.4296/cwrj3004297 
423 Gebrechorkos S H, Hülsmann S, Bernhofer C (2019) Statistically downscaled climate dataset for East Africa Sci Data 6: 31. https://doi.org/10.1038/s41597-019-0038-1

Gebremeskel S, Liu Y B, de Smedt F, Hoffmann L, Pfister L (2005) Analyzing the effect of climate changes on streamflow using statistically downscaled GCM scenarios. Int J River Basin Manag 2(4): 271-280. https://doi.org/10.1080/15715124.2004.9635237

Ghahraman B (2008) The estimation of one-day duration probable maximum precipitation over Atrak watershed in Iran. Iranian J Sci Technol 32: 175-179.

Gharibreza M R (2019) Huge Inundation (March 2019) of Golestan Province, Iran, Lessons that We Learned. Open Access J Environ Soil Sci 4(3): 507-510, DOI: 10.32474/OAJESS.2019.04.000188.

Hay L E, Wilby R L, Leavesley G H (2000) A comparison of delta change and downscaled GCM scenarios for three mountainous basins in the United States. J Am Water Resour Ass 36(2): 387-397. https://doi.org/10.1111/j.1752-1688.2000.tb04276.x

Hershfield D M (1961) Estimating the probable maximum precipitation. ASCE J. Hydraul Eng 87: 99-106.

Hershfield D M (1965) Method for estimating probable maximum precipitation. J Am Water Works Ass 57: 965-972.

Houghton J T, Ding Y, Griggs D J, Noguer M, Linden P J V d, Dai X, Johonson C A (2001) Climate Change (2001): The Scientific Basis: Contribution of Working Group I to the Third Assessment Report of IPCC.

Huang J, Zhang J, Zhang Z, Xu C, Wang B, Yao J (2011) Estimation of future precipitation change in the Yangtze River basin by using statistical downscaling method. Stoch Env Res Risk Ass 25(6): 781- 792. https://doi.org/10.1007/s00477-010-0441-9 
IPCC (2014) Summary for policymakers. In: C.B. Field, V.R. Barros, D.J. Dokken, K.J. Mach, M.D. Mastrandrea, T.E. Bilir, M. Chatterjee, K.L. Ebi, Y.O. Estrada, R.C. Genova, B. Girma, E.S. Kissel, A.N. Levy, S. MacCracken, P.R. Mastrandrea and L.L. White (Eds.) Climate Change (2014): Impacts, Adaptation, and Vulnerability. Part A: Global and Sectoral Aspects. Contribution of Working Group II to the Fifth Assessment Report of the Intergovernmental Panel on Climate Change. Cambridge and New York, NY: Cambridge University Press, pp. 132.

Joos B, Darakhani J, Mouvet L, Mehinrad A (2005) An integrated probabilistic approach for determining the effects of extreme hydrological events on a flood evacuation system, $73^{\text {rd }}$ annual meeting of ICOLD, Tehran, Iran.

Lee O, Kim S (2018) Estimation of Future Probable Maximum Precipitation in Korea Using Multiple Regional Climate Models. Water 10, 637. doi:10.3390/w10050637.

Lee J, Choi J, Lee O, Yoon J, Kim S (2017) Estimation of Probable Maximum Precipitation in Korea using a Regional Climate Model. Water 9: 240; doi:10.3390/w9040240.

Liu T, Liang Z, Chen Y, Lei X, Li B (2018) Long-duration PMP and PMF estimation with SWAT model for the sparsely gauged Upper Nujiang River Basin. Nat Hazards 90, 735-755. https://doi.org/10.1007/s11069-017-3068-z

MacLean A (2005) Statistical Evaluation of WATFLOOD (Ms). University of Waterloo, Ontario, Canada.

Mahmood R, Babel M S (2014) Future changes in extreme temperature events using the statistical downscaling model (SDSM) in the trans-boundary region of the Jhelum river basin. Weather Clim Extremes, 5: 56-66. https://doi.org/10.1016/j.wace.2014.09.001

Moss R H, Edmonds J A, Hibbard K A, Manning M R, Rose S K, Van Vuuren DP, Carter TR, Emori S, Kainuma M, Kram T, Meehl G A, Mitchell J F, Nalicenovic N, Riahi K, Smith SJ, 
Stouffer R J, Thomson A M, Weyant J P, Wilbanks T J (2010) The next generation of scenarios for climate change research and assessment. Nature 463: 747-756. $\underline{\text { https://doi.org/10.1038/nature08823 }}$

Nash J E, Sutcliffe J V (1970) River flow forecasting through conceptual models, Part I - a discussion of principles. J Hydrol 10(3): 282-290. http://dxdoiorg/101016/00221694(70)90255-6

Naseri Moghaddam M, Ghazanfari S, Ghahraman B, Davari K (2009) Probable maximum precipitation for 24-hour duration over four central provinces in Iran. World Environmental and Water Resources Congress, 1-6.

Nobilis F, Haiden T, Kerschbaum M (1991) Statistical Considerations Concerning Probable Maximum Precipitation (PMP) in the Alpine Country of Austria. Theor Appl Climatol 44: 8994. https://doi.org/10.1007/BF00867996

Palatella L, Miglietta M M, Paradisi P, Lionello P (2010) Climate change assessment for Mediterranean agricultural areas by statistical downscaling. Nat Hazards Earth Syst Sci 10: 1647- 1661. https://doiorg/105194/nhess-10-1647-2010

Papalexiou S M, Koutsoyiannis D (2006) A probabilistic approach to the concept of Probable Maximum Precipitation. Adv Geosci 7: 51-54. https://doiorg/105194/adgeo-7-51

Raghunath H M (2006) Hydrology: principles, analysis and design. New Age International 463 pages.

Rahimi J, Ebrahimpour M, Khalili A (2013) Spatial changes of extended De Martonne climatic zones affected by climate change in Iran. Theor Appl Climatol 112(3-4): 409-418. https://doi.org/10.1007/s00704-012-0741-8

Rakhecha P R, Singh V P (2009) Applied Hydrometeorology. Springer, 384 pp 
493 Rakhecha P R, Mandal B N, Kulkarni A K, Deshpande N R (1995) Estimation of Probable 494 Maximum Precipitation for Catchments in Eastern India by a Generalized Method. Theor Appl

495 Climatol, 51: 67-74

496

497

498

499

500

501

502

503

504

505

506

507

508

509

510

511

512

513

514

515

516

Rezacova D, Pesice P, Sokol Z (2005) An estimation of probable maximum precipitation for river basins in Czech Republic. J Atmos Res 77: 407-421. https://doi.org/10.1016/j.atmosres.2004.10.011

Rouhani H, Leconte R (2016) A novel method to estimate the maximization ratio of the Probable Maximum Precipitation (PMP) using regional climate model output. Water Resour Res 52: 7347-7365. https://doi.org/10.1002/2016WR018603

Salehnia N, Farid A, Hosseini F, Kolsoumi S, Zarrin A, Hasheminia M (2019) Comparing the performance of dynamical and statistical downscaling on historical run precipitation data over the semi-arid region. Asia-Pac J Atmospheric Sci 55(4): 737-749. DOI: 101007/s13143-019$\underline{00112-1}$

Sehgal V, Lakhanpal A, Maheswaran R, Khosa R, Sridhar V (2018) Application of multi-scale wavelet entropy and multi-resolution Volterra models for climatic downscaling. J Hydrol 55: 1078-1095. https://doi.org/10.1016/j.jhydrol.2016.10.048

Shaffie S, Mozaffari G. Khosravi Y (2019) Determination of extreme precipitation threshold and analysis of its effective patterns (case study: west of Iran). Nat Hazards 99, 857-878 https://doi.org/10.1007/s11069-019-03779-X

Sharifi F, Samadi S Z, Wilson C (2012) Causes and consequences of recent floods in the Golestan catchments and Caspian Sea regions of Iran. Nat Hazards, 61: 533-550. https://doi.org/10.1007/s11069-011-9934-1

Shirdeli A (2012) Probable maximum precipitation 24 hours estimation, A case study of Zanjan province of Iran. Manag Sci Lett 2: 2237-2242 
517 Soltani M, Khoshakhlagh F, Zawar-Reza P, Miller S T K, Molanejad M, Ranjbar Saadat Abadi, A

518 (2014) Probable maximum precipitation estimation using statistical and physical approaches

519 over Esfahan province of Iran. Res J For Environ Prot 1: 38-55.

520 Van Vuuren D P, Edmonds J, Kainuma M, Riahi K, Thomson A, Hibbard K, Hurtt G C, Kram T,

521 Krey V, Lamarque J F, Masui T (2011) The representative concentration pathways: an

522 overview. Clim Change 109: 5-31 doi:101007/s10584-011-0148-z

523 Vivekanandan N (2015) Estimation of Probable Maximum Precipitation Using Statistical

$524 \quad$ Methods. World J Res Rev (WJRR) 1: 13-16.

525 Wilby R L, Dawson C W, Barrow E M (2002) SDSM-a decision support tool for the assessment 526 of regional climate change impacts. Environ Model Softw 17(2): 145-157. $527 \quad$ https://doi.org/10.1016/S1364-8152(01)00060-3

528 Wilby R L, Dawson C W (2007) SDSM 42 - A decision support tool for the assessment of 529 regional climate change impacts User manual, 94 pages.

530 World Meteorological Organization (WMO) (1986) Manual for Estimation of Probable Maximum

531 Precipitation, Operational Hydrology Report 1, 2 ${ }^{\text {nd }}$ edition, Publication 332, World 532 Meteorological Organization, Geneva.

533 World Meteorological Organization (1988) Analyzing long time series of hydrological data with 534 respect to climate variability. World Meteorological Organization.

535 World Meteorological Organization (WMO) (2009) Manual on Estimation of Probable Maximum $536 \quad$ Precipitation, $3^{\text {rd }}$ edition, publication 1045 , Geneva. 